\title{
Subclinical hepatitis $C$ virus infection in Egyptian patients with rheumatic diseases: a multi-center study
}

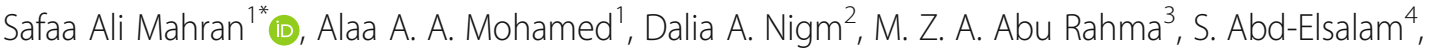 \\ Hesham Hamoud ${ }^{5}$, M. Hamdy ${ }^{5}$, M. I. Risha ${ }^{5}$, Ahmad Hamdy ${ }^{5}$, Mohamed M. Abdelkareem ${ }^{5}$ Saad Ghanem, \\ Mohamed Hanafy ${ }^{5}$, Abdelhafeez Moshrif ${ }^{6}$, A. Fehr ${ }^{7}$, Fatma H. ElNouby ${ }^{8}$, A. Osman ${ }^{9}$ and Manal M. Hassanien
}

\begin{abstract}
Background: Hepatitis C virus (HCV) infection is highly prevalent in Egypt. It was found to be $7.0 \%$ in a study done in 2015. There are some studies on the prevalence of HCV in rheumatoid arthritis, but to our knowledge, no previous study was done to detect it in other rheumatologic diseases. This study aims at detecting the prevalence of subclinical HCV infection in Egyptian patients with different rheumatic diseases. In the current study, eight hundred and three patients with different rheumatic diseases collected from five-geographically differentEgyptian rheumatology departments were studied. Patients with known current or previous HCV infection were excluded from the study. Screening for the positive anti-HCV antibodies was done for all patients. Screening for the presence of HCV ribonucleic acid (RNA) was done in patients with positive serology by reverse transcriptasepolymerase chain reaction.

Results: In the studied population, 675 (84.1\%) patients were women. The mean age [ \pm SD] was 44.2 [ \pm 12.9$]$ years. Hepatitis C antibody positivity was found in 73 (9.1\%) of the patients, while 67 (8.3\%) were having positive HCVRNA quantitative PCR tests. The highest prevalence of seropositive HCV was found in drug-induced vasculitis (DIV) and cryo-vasculitis (100\%), while in RA, HCV antibodies and PCR were found to be positive in $9.1 \%$ and $8.3 \%$ of patients, respectively.

Conclusions: Detection of the presence of HCV infection in $9.1 \%$ of the studied middle-aged Egyptian patients with rheumatologic conditions points to the importance of screening for HCV in such population for early detection and intervention especially for those patients that are planned to start biologic therapy.
\end{abstract}

Keywords: Hepatitis C virus; Rheumatologic diseases; Reactivation; Egypt

\section{Background}

Hepatitis $\mathrm{C}$ virus (HCV) infection is a worldwide major health problem that has health-related and economic impacts including heavy costs. It was estimated to be the 7th leading cause of mortality worldwide and affects 150-170 million people, including 19 million in Europe $[1,2]$. Egypt constitutes the country with the highest

\footnotetext{
* Correspondence: safaa69@yahoo.com; Safaa.mahran@aun.edu.eg

${ }^{1}$ Rheumatology, Rehabilitation and Physical Medicine, Faculty of Medicine,

Assiut University, Assiut, Egypt

Full list of author information is available at the end of the article
}

prevalence of $\mathrm{HCV}$ in the world, estimated nationally at $14.7 \%[3,4]$.

The spectrum of clinical manifestations of $\mathrm{HCV}$ infection can range from asymptomatic hepatitis flares to chronic hepatitis with hepatic decompensation, fulminant hepatic failure, and death in about $70-80 \%$ of cases due to liver cirrhosis and liver cancer. Therefore, identifying patients at risk and early diagnosis is imperative to decrease its significant morbidity and mortality [5].

Hepatitis $\mathrm{C}$ virus is a hepato- and lymphotropic agent that can trigger and sustain a clonal B cell expansion,

\section{Springer Open}

() The Author(s). 2020 Open Access This article is licensed under a Creative Commons Attribution 4.0 International License, which permits use, sharing, adaptation, distribution and reproduction in any medium or format, as long as you give appropriate credit to the original author(s) and the source, provide a link to the Creative Commons licence, and indicate if changes were made. The images or other third party material in this article are included in the article's Creative Commons licence, unless indicated otherwise in a credit line to the material. If material is not included in the article's Creative Commons licence and your intended use is not permitted by statutory regulation or exceeds the permitted use, you will need to obtain permission directly from the copyright holder. To view a copy of this licence, visit http://creativecommons.org/licenses/by/4.0/. 
and produce different autoantibodies causing a broad spectrum of autoimmune and lympho-proliferative disorders. This can complicate the differential diagnosis between primitive and $\mathrm{HCV}$-related rheumatic disorders [6]. Extrahepatic manifestations of HCV including rheumatologic disorders have been reported in up to two thirds of infected patients [7, 8]. These manifestations may include frank autoimmune and rheumatic diseases (such as myalgia, arthralgia, arthritis, vasculitis, and sicca syndrome) which may dominate and complicate the course of the disease; moreover, treatment with biologic agents could reactivate latent $\mathrm{HCV}$ infection [9].

Having been known with the highest HCV prevalence, yet the rate of rheumatic diseases associated with subclinical HCV remains poorly studied in Egypt. Therefore, we aimed to unveil the prevalence of subclinical HCV in Egyptian populations with different rheumatic diseases. We hypothesized that the rheumatic diseases may increase the vulnerability of the patients to get infected with $\mathrm{HCV}$ more than their peers from the general non-rheumatic population. To our knowledge, this is the first study on the prevalence of subclinical seropositive HCV in Egyptian patients with this number of different rheumatic conditions.

\section{Methods}

\section{Study population and design}

Five university centers participated in this multi-center, observational cross-sectional study. These centers were chosen in a way that ensures pooling of the study subjects from nearly all over the country. The two Delta centers received patients from different northern areas in Egypt, while the remaining 3 Upper Egypt centers received patients from southern areas in Egypt.

Each center obtained approval to this study from its Local Ethics Committee, respecting the ethical standards in the Helsinki Declaration of 1975, as revised in 2000. The clinical trial registration number is NCT03587714. Written consent was obtained from each participating subject prior to enrolment.

The study subjects were recruited from patients attending the outpatient Rheumatology Clinics in the aforementioned centers. Patients aged less than 18, pregnant females, patients with current or past history of viral hepatitis, and patients with secondary rheumatic manifestations or with end-organ failure were excluded.

The study was carried out in a 4 months' duration, starting from the beginning of May to the end of August 2017.

Demographic and clinical data were gathered from all patients using a unified questionnaire (Table 1). Diagnoses were made by a qualified rheumatologist according to the fulfillment of diagnostic criteria of different rheumatic diseases (e.g., ACR-EULAR 2012 criteria for RA, SLICC for lupus).
Table 1 Demographic data and medical status of the patients

\begin{tabular}{ll}
\hline Data & $\begin{array}{l}\text { Total no. of } \\
\text { patients }=803\end{array}$ \\
\hline $\begin{array}{l}\text { Age in years } \\
\text { (mean + Standard deviation) }\end{array}$ & $44.2 \pm 12.9$ \\
Gender, $n$ (\%) & \\
$\quad$ Female gender & $675(84.1)$ \\
$\quad$ Male gender & $128(15.9)$ \\
$\begin{array}{l}\text { Disease duration in years } \\
\text { (mean }+ \text { standard deviation) }\end{array}$ & $7.3 \pm 6$ \\
Positive anti-HCV, $n$ (\%) & $73(9.1)$ \\
Positive HCV PCR, $n$ (\%) & $67(8.3)$ \\
\hline
\end{tabular}

$H C V$ hepatitis $C$ virus, $P C R$ polymerase chain reaction

Routine lab works, e.g., CBC, ESR, CRP and other rheumatic diseases' specific autoantibodies to assist diagnoses of primary rheumatic diseases, were done. Liver function tests and HCV antibodies were also done for all participants. HCV-RNA quantitative PCR test was done for patients with positive HCV antibodies tests.

\section{Anti-HCV antibodies quantification}

Serum samples withdrawn from patients were stored at $-20{ }^{\circ} \mathrm{C}$. Serum anti-HCV antibodies levels were analyzed on ARCHITECT i1000SR Immunoassay (Abbott Diagnostics, Europe), using chemiluminescence/magnetic particle. The results were represented as serum to cutoff ratio $(\mathrm{S} / \mathrm{CO})$. All samples were tested in duplicates.

\section{HCV-RNA quantification}

Serum HCV-RNA levels were analyzed by reverse transcriptase-polymerase chain reaction (RT-PCR) on 7500 Fast Real-Time instrument. The results were represented as international unit per milliliter $(\mathrm{IU} / \mathrm{mL})$. All samples were tested in duplicates.

\section{Statistical analysis}

The descriptive data were presented as number and percentage $(N, \%)$, and mean and standard deviation (mean, $\mathrm{SD})$. Cross tabulation was done by chi-square test. All statistical analyses were carried out using the Statistical Package for Social Science (SPSS) version 24 (SPSS Inc.; Chicago, IL, USA).

\section{Results}

A total of 803 rheumatic patients from five different Rheumatology centers in Egypt were recruited in this study. The mean age of our patients was $44.2 \pm 12.9$ years, most of them were females 675 (84.1\%), and the mean disease duration was $7.3 \pm 6$ years. Hepatitis C positivity was found in $73(9.1 \%)$ of the 3

Over half of the patients 483 (66.1\%) were diagnosed to have rheumatoid arthritis, while systemic lupus was 
diagnosed in 96 (12\%) patients. Forty-four patients (5.5\%) had osteoarthritis (OA) and Behcet's disease was found in $27(3.4 \%)$ patients. Only 3 patients $(0.4 \%)$ were having polyarthralgia of no cause except vitamin $\mathrm{D}$ deficiency with mean serum level of $12.03 \pm 2.5 \mathrm{ng} / \mathrm{ml}$. The rest of the patients had other rheumatic diseases with different frequencies as shown in Table 2.

Table 2 Frequency of rheumatic diseases in the cohort

\begin{tabular}{|c|c|}
\hline Rheumatic diseases & Total $n=803$ \\
\hline RA & $483(60.1 \%)$ \\
\hline SLE & $96(12 \%)$ \\
\hline OA & $44(5.5 \%)$ \\
\hline Non-specific rheumatic manifestations* & $36(4.5 \%)$ \\
\hline $\mathrm{BD}$ & $27(3.4 \%)$ \\
\hline AS & $17(2.1 \%)$ \\
\hline SSC & $14(1.7 \%)$ \\
\hline SS & $11(1.4 \%)$ \\
\hline FMS & $10(1.2 \%)$ \\
\hline CPPD & $9(1.1 \%)$ \\
\hline Gout & $7(0.9 \%)$ \\
\hline Overlap syndrome (RA+SLE) & $7(0.9 \%)$ \\
\hline SPA & $6(0.7 \%)$ \\
\hline IDM & $6(0.7 \%)$ \\
\hline PsA & $5(0.6 \%)$ \\
\hline Cryo-vasculitis & $4(0.5 \%)$ \\
\hline Sarcoidosis & $3(0.4 \%)$ \\
\hline PA & $3(0.4 \%)$ \\
\hline GCA+PMR & $2(0.2 \%)$ \\
\hline JIA & $2(0.2 \%)$ \\
\hline MCTD & $2(0.2 \%)$ \\
\hline Vasculitis & $2(0.2 \%)$ \\
\hline WG & $1(0.1 \%)$ \\
\hline MPA & $1(0.1 \%)$ \\
\hline DIV & $1(0.1 \%)$ \\
\hline Palindromic rheumatism & $1(0.1 \%)$ \\
\hline Overlap syndrome (RA+SSc) & $1(0.1 \%)$ \\
\hline AOSD & $1(0.1 \%)$ \\
\hline APS & $1(0.1 \%)$ \\
\hline
\end{tabular}

$R A$ rheumatoid arthritis, SLE systemic lupus erythematosus, OA osteoarthritis, $B D$ Behcet's disease, $A S$ ankylosing spondylitis, SSC systemic sclerosis, SS Sjogren's syndrome, FMS fibromyalgia syndrome, CPPD calcium pyrophosphate dehydrogenate deposition disease, SPA spondyloarthropathy, IDM inflammatory dermatomyositis, $P S A$ psoriatic arthritis, $P A$ polyarthralgia due to vitamin D deficiency, GCA giant cell arteritis, PMR polymyalgia rheumatica, JA juvenile-onset inflammatory arthritis, MCTD mixed connective tissue disease, WG Wagner's granulomatosis, MPA microscopic polyangiitis, DIV drug-induced vasculitis, AOSD: adult-onset Still's disease, APS antiphospholipid syndrome *Non-specific rheumatic manifestations included tendinitis, tendinopathy, bursitis, osteomalacia, bone pain, non-inflammatory back pain, or neuropathic pain
The distribution of cases with positive $\mathrm{HCV}$ antibodies and positive PCR among the 5 different centers is demonstrated in Table 3. All patients with positive HCV antibody had positive PCR testing except in 3 centers where 8 patients had positive antibody and negative PCR. In one center, isolated positive PCR was found in a total of 2 patients.

The distribution of seropositive $\mathrm{HCV}$ and positive PCR among different rheumatic conditions is presented in Table 4. The highest prevalence of seropositive HCV was found in drug-induced vasculitis (DIV) and cryo-vasculitis (100\%), followed by polyarthralgia (66.7\%) and gout (28.6). In RA, HCV antibodies and PCR were found to be positive in $8.4 \%$ and $8.3 \%$ of patients, respectively. Negative HCV antibodies were reported in some cases including Behcet's disease, calcium pyrophosphate dehydrogenate deposition disease (CPPD), Sjogren's, sarcoidosis, mixed connective tissue diseases, juvenile-onset idiopathic arthritis (JIA), Wagner's granulomatosis (WG), palindromic rheumatism, primary fibromyalgia, adult-onset Still's disease, and antiphospholipid syndrome.

\section{Discussion}

Egypt was reported previously to be among the areas with the highest prevalence of $\mathrm{HCV}$ infection in the world. It accounted for up to $40 \%$ in some areas [10-13]. However, the prevalence of this infection has not been determined in rheumatic diseases where it could have a role in their evolution or management. To our knowledge, this is the first study on the prevalence of subclinical seropositive $\mathrm{HCV}$ in Egyptian patients with this number of different rheumatic conditions.

In this study, the prevalence of positive $\mathrm{HCV}$ antibodies and positive PCR in the studied population was found to be $9.1 \%$ and $8.3 \%$, respectively. In a recent epidemiological study on Egyptian populations, patients with rheumatic conditions were classified as "Special clinical population" among 6 groups of populations at risk of exposure to hepatitis $\mathrm{C}$ infection. In this population, the prevalence of positive hepatitis $\mathrm{C}$ antibodies ranged from 6.7 to $96.1 \%$ with a median of $38.0 \%$. This very wide range can be explained by the fact that they included in this study patients with dermatological diseases and non-hepatic malignancies [14].

The pooled mean prevalence of anti-HCV antibodies among the same population was $35.0 \%(95 \% \mathrm{CI}=27.3$ 43.1\%). Furthermore, the incidence of hepatitis $\mathrm{C}$ infection was found to be higher in the residents of the villages of the Nile Delta compared with residents of the villages of Upper Egypt (10.2 per 1.000 persons versus 0.8 per 1.000 persons, respectively). Their findings suggest that HCV screening in the "special clinical population" should be given a priority [14]. 
Table 3 Distribution of seropositive HCV and positive PCR patients among the study centers

\begin{tabular}{|c|c|c|c|c|}
\hline Study center & & Total patients & Positive anti-HCV, n (\%) & Positive HCV PCR $n(\%$ \\
\hline \multirow[t]{2}{*}{ Delta Centers } & Center 1 & 101 & $10(9.9)$ & $10(9.9)$ \\
\hline & Center 2 & 387 & $36(9.3)$ & $31(8)$ \\
\hline \multirow[t]{3}{*}{ Upper Egypt Centers } & Center 3 & 215 & $21(9.8)$ & $19(8.8)$ \\
\hline & Center 4 & 61 & $2(3.3)$ & $4(6.6)$ \\
\hline & Center 5 & 39 & $4(10.3)$ & $3(7.7)$ \\
\hline Total number & & 803 & $73(9.1)$ & $67(8.3)$ \\
\hline
\end{tabular}

$H C V$ hepatitis $C$ virus, $P C R$ polymerase chain reaction, $n$ number

In agreement with the previous finding, we recorded a high prevalence of positive $\mathrm{HCV}$ antibodies and PCR (9.9\%) each in the patients recruited from center 2 (of a Delta city), while the lowest prevalence $(3.3 \%, 6.6 \%$ respectively) was recorded in patients recruited from center 4 (Upper Egypt).

The association between HCV infection and rheumatic diseases especially RA has been reported in many studies. The prevalence of chronic HCV infection in rheumatic patients varied according to the study site, which could reflect differences in the prevalence of HCV among different countries. Some Brazilian and Spanish studies reported the high prevalence of seropositive HCV infection in patients with rheumatic diseases $[15,16]$.

In the current study, the prevalence of positive $\mathrm{HCV}$ antibodies and positive PCR in RA patients was $8.5 \%$ and $8.3 \%$, respectively. This is markedly higher than what was reported by Maillefert et al. who found that positive $\mathrm{HCV}$ antibodies and positive PCR among RA patients were $0.85 \%$ and $0.42 \%$, respectively [17].

Table 4 Distribution of the anti-HCV-positive and PCR-positive patients among different diseases

\begin{tabular}{lll}
\hline Diagnosis & Anti-HCV positive & Positive PCR \\
\hline AS & $2(11.8 \%)$ & 0 \\
Cryo-vasculitis & $4(100 \%)$ & $3(75 \%)$ \\
DIV & $1(100 \%)$ & $1(100 \%)$ \\
Gout & $2(28.6 \%)$ & $2(28.6 \%)$ \\
OA & $7(15.9 \%)$ & $4(9.1 \%)$ \\
PA & $2(66.7 \%)$ & $2(66.7 \%)$ \\
PSA & $1(20 \%)$ & $1(20 \%)$ \\
RA & $41(8.5 \%)$ & $40(8.3 \%)$ \\
SLE & $5(5.2 \%)$ & $4(4.2 \%)$ \\
SSC & $1(7.1 \%)$ & $1(7.1 \%)$ \\
Non-specific rheumatic manifestations & $7(19.4 \%)$ & $9(25 \%)$ \\
Total & $73(9.1 \%)$ & $67(8.3 \%)$ \\
\hline
\end{tabular}

$A S$ ankylosing spondylitis, DIV drug-induced vasculitis, $O A$ osteoarthritis, $P A$ polyarthralgia due to vitamin $\mathrm{D}$ deficiency, PsA psoriatic arthritis, $R A$ rheumatoid arthritis, SLE systemic lupus erythematosus, SSC systemic sclerosis Non-specific rheumatic manifestations included tendinitis, tendinopathy, bursitis, osteomalacia, bone pain, non-inflammatory back pain, or neuropathic pain
This great difference could be explained by the endemicity of $\mathrm{HCV}$ in Egypt. There is some evidence of the critical role of the liver in modulating the immune response in chronic inflammatory and autoimmune conditions [18-20].

It was denoted in the literature that autoimmune and lympho-proliferative diseases are well-known $\mathrm{HCV}$ related disorders [21]. However, many studies failed to find a positive association between $\mathrm{HCV}$ infection and RA, with no support for the participation of $\mathrm{HCV}$ in the pathogenesis of RA [15, 17, 22]. A nationwide study done in Taiwan reported that patients with HCV infection were at higher risk of developing RA later [23].

Some studies found that arthralgia and arthritis were the most common extrahepatic manifestations of chronic HCV infection $[24,25]$. Others claim that there is high prevalence of seropositive HCV among rheumatologic patients $[15,16]$.

This goes in line with our finding where seropositive $\mathrm{HCV}$ was found in $(100 \%)$ of patients with drug-induced vasculitis and cryo-vasculitis, followed by polyarthralgia (66.7\%) and gout (28.6). A possible explanation could be that the state of chronic viremia may trigger these diseases in genetically predisposed persons. Two out of the $3(66.7 \%)$ patients with polyarthralgia were positive for HCV antibodies and PCR. Several studies had reported the high prevalence of vitamin D deficiency in all chronic hepatic diseases irrespective of their etiology [26-28]. Serum vitamin D level $<20 \mathrm{ng} / \mathrm{ml}$ was found to be highly prevalent in patients with chronic hepatitis $\mathrm{B}$ and C worldwide [29]. Furthermore, vitamin D deficiency was delineated to contribute in the pathogenesis of hepatitis $B$ and $C$ and lead to progression of hepatic inflammation and fibrosis [30].

It was reported that clinically evident vasculitis occurs in less than $5 \%$ of $\mathrm{HCV}$ infected subjects with typical manifestations of purpura, weakness, and arthralgia [6, 31, 32].

Although circulating mixed cryoglobulins are detected in $40-60 \%$ of patients chronically infected with $\mathrm{HCV}$, overt cryo-vasculitis is observed in only $5-10 \%$ of cases. HCV infection represents the cause of cryovasculitis in $70-80 \%$ of cases as Cacoub and his colleagues found [33-35]. 
We did not detect $\mathrm{HCV}$ antibodies in some rheumatic diseases including Behcet's disease, CPPD, Sjogren's, sarcoidosis, mixed connective tissue diseases, JIA, WG, palindromic rheumatism, primary fibromyalgia, adultonset Still's disease, and antiphospholipid syndrome.

Although anti-HCV antibodies were found in $15.2 \%$ of fibromyalgia patients in a Spanish study [36], the increased prevalence of $\mathrm{HCV}$ infection in such condition was not confirmed by other studies [37]. However, HCV infection should be kept in mind as a possible cause of secondary fibromyalgia [7].

Detection of seropositive HCV antibodies denotes either active or past infection while detecting the state of viremia assessed by PCR test is a powerful indicator of chronic $\mathrm{HCV}$ infection. In this study, 8 patients with positive $\mathrm{HCV}$ antibodies were having negative PCR. In one center, isolated positive PCR was found in a total of 2 patients. The occurrence of positive PCR with negative HCV serology can be found but in very low prevalence [38, 39], and this denotes an occult $\mathrm{HCV}$ infection, which necessitates testing of both HCV antibodies and PCR in all patients.

This study had some limitations including the smallsized population collected from some centers and the cross-sectional type of the study. The great difference in the number of patients in different disease groups was also a weak point. In this study, PCR testing was performed in seropositive $\mathrm{HCV}$ cases only, while it would be ideal to perform it in all the participants to detect occult HCV infection.

\section{Conclusion}

In conclusion, considering the endemicity of $\mathrm{HCV}$ in Egypt and the detection of positive antibody titer in 9.1\% of the study patients, regular screening of Egyptian rheumatic patients for HCV infection may not be necessary for the detection of subclinical cases. Rheumatic diseases seem to have no effect on increasing the susceptibility of the patients to get infected by HCV. However, for patients planned to receive biologic therapy, it is a well-known recommendation to have screening for $\mathrm{HCV}$ and HBV before initiation of biological treatment.

\section{Abbreviations}

HCV: Hepatitis C virus; ACR: American College of Rheumatology; EULAR: European League Against Rheumatism; RA: Rheumatoid arthritis; SLICC: Systemic Lupus Collaborating Clinics; CBC: Complete blood count; ESR: Erythrocyte sedimentation rate; CRP: C reactive protein; RNA: Ribonucleic acid; SPSS: Statistical Package for Social Science; CPPD: Calcium pyrophosphate dehydrogenate deposition disease; WG: Wagner's granulomatosis; PCR: Polymerase chain reaction; HBV: Hepatitis B virus; SLE: Systemic lupus erythematosus; OA: Osteoarthritis; BD: Behcet's disease; AS: Ankylosing spondylitis; SSc: Systemic sclerosis; SS: Sjogren's syndrome; FMS: Fibromyalgia syndrome; SPA: Spondyloarthropathy; IDM: Inflammatory dermatomyositis; PsA: Psoriatic arthritis; PA: Polyarthralgia associated with hypovitaminosis D; GCA: Giant cell arteritis; PMR: Polymyalgia rheumatica; JIA: Juvenile-onset inflammatory arthritis; MCTD: Mixed connective tissue disease; MPA: Microscopic polyangiitis; DIV: Drug-induced vasculitis; AOSD: Adult-onset Still's disease; APS: Antiphospholipid syndrome

\section{Acknowledgements}

Not applicable

\section{Authors' contributions}

S M: Conception and design, critical revision of the submitted protocol for important intellectual content, acquisition of data, analysis and interpretation of data, and writing the manuscript. A M: Statistical analysis. D N and O A: Laboratory work out. M R: Conception, design, and administrative tasks. S A: Critical revision of the submitted protocol for important intellectual content and revision of the manuscript. $\mathrm{H} \mathrm{H}$ : Administrative and supervision. $\mathrm{M} \mathrm{H}, \mathrm{M}$ R, A H, M M A, S G, M H, A M, A F, and F E: Acquisition of data, analysis, and interpretation of data. $\mathrm{M} \mathrm{H}$ : Conception and design, acquisition of data, analysis and interpretation of data, critical revision of the submitted protocol for important intellectual content, and drafting of the submitted protocol. All authors read and approved the final manuscript.

Funding

No funding from an external organization or body was needed.

\section{Availability of data and materials}

The datasets used and/or analyzed during the current study are available from the corresponding author on reasonable request.

\section{Ethics approval and consent to participate}

This study has been approved by the local ethics committee of Faculty of Medicine, Assiut University, and each collaborating center attained approval from its local ethical committee and conforms to the guidelines of the Declaration of Helsinki.

Final approval of the research from the local ethical committee was obtained under the ID number of 17300384 at April 22, 2017

Clinical trial registration no. NCT03587714

Written consents were collected from the participants before enrollment in the study.

Consent for publication

Not applicable

\section{Competing interests}

The authors declare that they have no competing interests.

\section{Author details}

${ }^{1}$ Rheumatology, Rehabilitation and Physical Medicine, Faculty of Medicine, Assiut University, Assiut, Egypt. ${ }^{2}$ Clinical Pathology, Assiut University, Assiut, Egypt. ${ }^{3}$ Tropical Medicine, Assiut University, Assiut, Egypt. ${ }^{4}$ Tropical Medicine, Tanta University, Tanta, Egypt. ${ }^{5}$ Rheumatology and Rehabilitation, AL-Azhar University, Cairo, Egypt. ${ }^{6}$ Rheumatology and Rehabilitation, Al-Azhar University, Assiut, Egypt. ${ }^{7}$ Rheumatology and Rehabilitation, Helwan University, Cairo, Egypt. ${ }^{8}$ Rheumatology and Rehabilitation, Aswan University, Aswan, Egypt. ${ }^{9}$ Clinical and Chemical Pathology, Aswan University, Aswan, Egypt.

Received: 21 April 2020 Accepted: 18 May 2020

Published online: 08 September 2020

References

1. Lavanchy D (2011) Evolving epidemiology of hepatitis C virus. Clin Microbiol Infect 17(2):107-115.3

2. Negro F (2014) Epidemiology of hepatitis C in Europe. Dig Liver Dis off J Ital Soc Gastroenterol Ital Assoc Study Liver 46(5):S158-S164

3. Ahmed OA, Safwat E, Khalifa MO et al (2018) Sofosbuvir plus daclatasvir in treatment of chronic hepatitis $C$ genotype 4 infection in a cohort of Egyptian patients: an experiment the size of Egyptian village. Int J Hepatol. 2018:1-5

4. Abd-Elsalam S, Sharaf-Eldin M, Soliman S et al (2018) Efficacy and safety of sofosbuvir plus ribavirin for treatment of cirrhotic patients with genotype 4 hepatitis C virus in real-life clinical practice. Arch Virol 163(1):51-56

5. Antonelli A, Ferri C, Galeazzi M et al (2008) HCV Infection: pathogenesis, clinical manifestations and therapy. Clin Exp Rheumatol 26:S39-\$47

6. Ferri C, Sebastiani M, Giuggioli D et al (2015) Hepatitis C virus syndrome: a constellation of organ- and non-organ specific autoimmune disorders, B-cell non-Hodgkin's lymphoma, and cancer. World J Hepatol 7:327-343 
7. Palazzi C, Olivieri I, Cacciatore P et al (2005) Difficulties in the differential diagnosis between primitive rheumatic diseases and hepatitis $C$ virusrelated disorders. Clin Exp Rheumatol 23:2-6

8. Palazzi C, Buskila D, D'Angelo $S$ et al (2012) Autoantibodies in patients with chronic hepatitis $C$ virus infection: pitfalls for the diagnosis of rheumatic diseases. Autoimmun Rev 11:659-663

9. Cacoub P, Comarmond C (2017) New insights into HCV-related rheumatologic disorders: a review. J Adv Res 8:89-97

10. Darwish MA, Raouf TA, Rushdy P et al (1993) Risk factors associated with a high seroprevalence of hepatitis $C$ virus infection in Egyptian blood donors. Am J Trop Med Hyg. 49(4):440-447

11. Arthur RR, Hassan NF, Abdallah MY et al (1997) Hepatitis C antibody prevalence in blood donors in different governorates in Egypt. Trans R Soc Trop Med Hyg. 91(3):271-274

12. Abdel-Aziz F, Habib M, Mohamed MK et al (2000) Hepatitis C virus (HCV) infection in a community in the Nile Delta: population description and HCV prevalence. Hepatology. 32(1):111-115

13. Darwish M, Faris R, Clemens J et al (1996) High seroprevalence of hepatitis $A, B, C$, and $E$ viruses in residents in an Egyptian village in the Nile Delta: a pilot study. Am J Trop Med Hyg. 54(6):554-558

14. Kouyoumjian SP, Chemaitelly H, Abu-Raddad LJ (2018) Characterizing hepatitis C virus epidemiology in Egypt: systematic reviews, meta-analyses, and metaregressions. Cientific reports 8:1661

15. Rivera J, Garcia-Monforte A, Pineda A et al (1999) Arthritis in patients with chronic hepatitis C virus infection. J Rheumatol 26:420-424

16. Barbosa VS, Silva NA, Martins RM (2005) Hepatitis C virus seroprevalence and genotypes in patients with diffuse connective tissue diseases and spondyloarthropathies. Braz J Med Biol Res 38:801-805

17. Maillefert JF, Muller G, Falgarone $G$ et al (2002) Prevalence of hepatitis $C$ virus infection in patients with rheumatoid arthritis. Ann Rheum Dis 61:635-637

18. Zhou P, Wirthlin L, McGee J et al (2009) Contribution of human hematopoietic stem cells to liver repair. Semin Immunopathol 31:411-419

19. Padgett KA, Lan RY, Leung PC et al (2009) Primary biliary cirrhosis is associated with altered hepatic microRNA expression. J Autoimmun 32:246-253

20. Tiegs G, Lohse AW (2010) Immune tolerance: what is unique about the liver? J Autoimmun 34:1-6

21. Zignego AL, Giannini C, Monti M et al (2007) Hepatitis C virus lymphotropism: lessons from a decade of studies. Dig Liver Dis off J Ital Soc Gastroenterol Ital Assoc Study Liver 39(1):S38-S45

22. Taglione E, Vatteroni ML, Martini P et al (1999) Hepatitis C virus infection: prevalence in psoriasis and psoriatic arthritis. J Rheumatol 26:370-372

23. Su FH, Wu CS, Sung FC et al (2014) Chronic hepatitis C virus infection is associated with the development of rheumatoid arthritis: a nationwide population- based study in Taiwan. PLoS ONE 9(11):e113579

24. Chi ZC, Ma SZ (2003) Rheumatologic manifestations of hepatic diseases. Hepatobiliary Pancreat Dis Int 2:32-37

25. Cacoub P, Poynard T, Ghillani P et al (1999) Extrahepatic manifestations of chronic hepatitis C. MULTIVIRC Group. Multidepartment Virus C. Arthritis Rheum 42:2204-2212

26. Stokes CS, Volmer DA, Grünhage F, Lammert F. Vitamin D in chronic liver disease. Liver Int 2013; 33: 338-352 [PMID: 23402606 DOl: https://doi.org/10. 1111/liv.12106]

27. Chan HL, Elkhashab M, Trinh H, Tak WY, Ma X, Chuang WL, Kim YJ, Martins EB, Lin L, Dinh P, Charuworn P, Foster GR, Marcellin P. Association of baseline vitamin $D$ levels with clinical parameters and treatment outcomes in chronic hepatitis B. J Hepatol 2015; 63: 1086-1092 [PMID: 26143444 DOI: 10.1016/ j.jhep.2015.06.025]

28. Wong GL, Chan HL, Chan HY, Tse CH, Chim AM, Lo AO, Wong WW. Adverse effects of vitamin $D$ deficiency on outcomes of patients with chronic hepatitis B. Clin Gastroenterol Hepatol 2015; 13: 783-790.e1 [PMID: 25445773 DOl: 10.1016/ j.cgh.2014.09.050]

29. Hoan NX, Van Tong H, Le Huu Song CG, Velavan TP (2018) Vitamin D deficiency and hepatitis viruses-associated liver diseases: a literature review. World journal of gastroenterology. 24(4):445

30. Targher G, Bertolini L, Scala L, Cigolini M, Zenari L, Falezza G, Arcaro G. Associations between serum 25-hydroxyvitamin D3 concentrations and liver histology in patients with non-alcoholic fatty liver disease. Nutr Metab Cardiovasc Dis 2007; 17: 517-524 [PMID: 16928437 DOI: 10.1016/j.numecd. 2006.04.002]
31. Ferri C (2008) Mixed cryoglobulinemia. Orphanet J Rare Dis 3:25

32. Ferri C, Sebastiani M, Giuggioli D et al (2004) Mixed cryoglobulinemia: demographic, clinical, and serologic features and survival in 231 patients. Semin Arthritis Rheum 33:355-374

33. Cacoub P, Comarmond C, Domont F et al (2015) Cryoglobulinemia vasculitis. Am J Med 128(9):950-955

34. Cacoub P, Gragnani L, Comarmond C et al (2014) Extrahepatic manifestations of chronic hepatitis C virus infection. Dig Liver Dis Off J Ital Soc Gastroenterol Ital Assoc Study Liver 46(5):S165-S173

35. Cacoub P, Comarmond C, Domont F et al (2016) Extrahepatic manifestations of chronic hepatitis $C$ virus infection. Ther Adv Infect Dis 3(1):3-14

36. Narváez J, Nolla JM, Valverde-García J (2005) Lack of association of fibromyalgia with hepatitis C virus infection. J Rheumatol 32:1118-1121

37. Palazzi C, D'Amico E, D'Angelo $S$ et al (2008) Hepatitis C virus infection in Italian patients with fibromyalgia. Clin Rheumatol 27:101-103

38. Dubois F, Desenclos JC, Mariotte N et al (1997) Hepatitis C in a French population-based survey, 1994: seroprevalence, frequency of viremia, genotype distribution, and risks factors. Hepatology 25:1490-1496

39. Austria A, George YW (2018) Occult hepatitis C virus infection: a review. J Clin Transl Hepatol 6:155-160

\section{Publisher's Note}

Springer Nature remains neutral with regard to jurisdictional claims in published maps and institutional affiliations.

\section{Submit your manuscript to a SpringerOpen ${ }^{\circ}$ journal and benefit from:}

- Convenient online submission

- Rigorous peer review

- Open access: articles freely available online

High visibility within the field

- Retaining the copyright to your article

Submit your next manuscript at $\boldsymbol{\nabla}$ springeropen.com 